\title{
Changes in Levels of Economic Development among the States Formed in the Area of Former Yugoslavia
}

\author{
Zoran Stiperski, Jelena Lončar
}

\begin{abstract}
After a long period, during the Yugoslav epoch, in which there were no changes in the levels of economic development of the constitutive republics, major changes occurred following the break-up of Yugoslavia. The western republics - today independent Slovenia and Croatia - rapidly advanced and notably diverged from the former eastern republics. The range of differences in development levels became surprisingly large in the area of the former shared state. At the same time, economic cooperation between countries in the ex-Yugoslav area decreased. Most recently there has been an increase in such cooperation, yet its extent is still much lower than before the break-up of Yugoslavia. The present differences in the levels of development between the western and the eastern states (independent countries) will presumably decrease in the future-however, for some time to come, for at least one or two decades, these differences will remain greater than they were during the period before 1990, i.e. when the Federal Socialist Republic of Yugoslavia still existed.
\end{abstract}

Key words: economic development, regional development, former Yugoslavia, Croatia

\section{Promjene u razinama ekonomske razvijenosti zemalja nastalih na području bivše Jugoslavije}

Nakon dužeg razdoblja nikakvih promjena u razini gospodarske razvijenosti republika tijekom jugoslavenskog razdoblja, raspadom Jugoslavije dolazi do velikih promjena. Zapadne republike, sada države, Slovenija i Hrvatska ubrzano se odmiču i značajno se udaljavaju od istočnih. Raspon u razvijenosti postao je iznenađujuće velik u nekada istoj državnoj zajednici. Istovremeno dolazi do smanjenja suradnje između država s bivšeg jugoslavenskog prostora. U najnovije vrijeme dolazi do jačanja suradnja među novonastalim državama, ali je razina te suradnja znatno manje jakosti nego prije raspada Jugoslavije. Pretpostavka je da će doći do smanjenja tako velikih razlika u razini razvijenosti između zapadnih i istočnih država, ali će jedno vrijeme, barem jedno do dva desetljeća, razlike biti veće nego u razdoblje do 1990. g. kada je postojala Jugoslavija.

Ključne riječi: ekonomski razvoj, regionalni razvoj, bivša Jugoslavija, Hrvatska 


\section{INTRODUCTION}

The aim of this paper is twofold: 1) to determine changes in the levels of economic development among the republics/countries in the area of former Yugoslavia, and 2) to examine the levels of mutual economic cooperation and interlinking between the various units in question. Here we must stress that this paper will not address the topic of different economic systems in the individual countries. Let us just say that this entire area has been shifting from one economic system to another - from a self-managed socialist economy (a form of the socialist or state-directed command economy that in the recent past prevailed in East Europe and in the USSR), to a capitalist or rather market-based economy. The new system is much more open to foreign influences, much less under state influence and it demands much more individual entrepreneurial activity and initiative from individuals, which is quite difference than was the case in the former system. This economic shift has been very difficult; its duration has been long enough to be called a transition period and its economic form is sufficiently particular to be denoted as a transitional economy.

The break-up of Yugoslavia and the wars in the region caused a partial collapse of the Yugoslav market, which, together with various international sanctions, treats of sanctions, and the usual agonies of war, made it even more difficult to successfully shift to a well-functioning market economy. The actual move to the market economy was in itself quick, better said hasty. There had been little suitable preparation and adjustment of legislation, due to impatience, various international pressures to accept "shock therapy" (instant changes, despite poor preparation), and also due to the assumptions of domestic elites that a better-ordered legal system would reduce the "creative" zone for actions during the privatisation process. One must add, of course, that there had not been any previous examples in the world to provide guidelines during this process, since former Yugoslavia, East Europe and the USSR, were the first areas in the world to experience such a transition from socialism to market economies. Today many different types of capitalism exist in the world; their forms in the area of ex-Yugoslavia range from mixed economies or social welfare states (the West European type of capitalism), to forms of liberal (laissez-faire) capitalism (of the American type) and predatory capitalism (the new Russian type of capitalist).

This paper began with two assumptions, which were to a large extent confirmed. The first was that greater differences emerged in the levels of development of the republics/countries in the period examined, especially after the break-up of Yugoslavia in 1990. The assumption was that the developed former Yugoslav republics, Slovenia and Croatia, became even more developed after gaining independence, and that Serbia together with Montenegro lagged behind, and fell behind even more after 1990. The second assumption was that economic cooperation between the newly independent states in the area of former Yugoslavia significantly decreased, as is to be expected after the break-up of a state formation. A further assumption was that the economic focus of the newly independent countries shifted towards the West (towards Europe and the US) and to the broader world community, and away from their immediate ex-Yugoslav vicinity and the non-aligned world.

This paper is divided into two main sections. The first treats the levels of development of the individual republics and later countries in the former Yugoslav area. The period 
examined extends from 1957 to 2005 . We chose this period since we wished to cover the longest possible time-range prior to the break-up of Yugoslavia (and the year 1957 is the first year for which comparable data is available). We were interested in the dynamics of long-term economic development during the socialist Yugoslav period, and not just in developments during the transitional periods of the independent successor states. Two basic indicators of development were used: total domestic/national income and per capita national income. Due to different currencies (the Yugoslav dinar in the Yugoslav period, the American dollar in international comparisons in the post-Yugoslav period), as well as due to the continuous devaluation of these currencies in the long period, the dynamics of economic development were examined based on the share of the individual republics in the Yugoslavia economy or of the individual countries in the aggregate economy of the former Yugoslav region. In this way a clear picture emerged of the development of individual republics/countries within Yugoslavia and relative to the ex-Yugoslav area, but not relative to the European area, or the rest of the world. Hence, using this method the economic development of the individual republics/countries cannot be compared with the development of states outside of the former Yugoslavia area, such as Hungary or Austria.

The second topic that the paper discusses is economic cooperation between the individual republics/countries, with particular emphasis on the period after the break-up of Yugoslavia. We based this analysis on data pertaining to direct foreign investments and international trade. In addition to determining economic cooperation, we made an attempt to ascertain the direction (focus) of economic orientations of the individual republics/countries. To do this we analysed published headlines from daily newspapers as a possible source of information, since they are comparable through time and in various spatial contexts, and are also indicative of future developments.

Yet the availability of data was rather limited. With such sparse information we attempted to draw the broadest and most wide-ranging picture of the recent changes that we could. It is important to note that the World Bank began to publish some basic information for Serbia and Montenegro only in 2000. Therefore, for an entire decade, the 1990s, we do not have official and precise data for Serbia and Montenegro, although the World Bank did provide some orientational estimates. We attempted to obtain exact data from serious organisations, in order to produce the most accurate comparisons possible between the individual republics. For the Yugoslav period, 1957-1988, we used Yugoslav statistical data, since international organisations usually do not publish data on internal territorial divisions, in this case in regard to the republics of the former Yugoslav federation.

\section{DISCUSSION}

\section{a) Economic Development of the Republics/Countries from 1957 to 2005}

There was virtually no change in the share of the individual republics in Yugoslavia's total domestic product during the examined period, 1957-1988. The relative shares of the individual republics remained for many years the same. Thus, their ratios of participation in the gross domestic product (GDP) were static in the long-term. No republic showed either a significant increase or decrease in its relative share. 
Yugoslavia consisted of six republics and two autonomous regions - Voivodina and Kosovo, which were part of Serbia. The tables in this paper present data for four republics that became independent states after 1991: 1) Croatia, 2) Slovenia, 3) Bosnia and Herzegovina and 4) Macedonia, and grouped data for the two republics that remained in one state -5 ) Serbia and Montenegro. This joint state, formed by republics of Serbia and Montenegro, was first called the Federal Republic of Yugoslavia, and later simply Serbia and Montenegro. We grouped the republics of Serbia and Montenegro into one entity when presenting data from the Yugoslav period, since this enables comparisons to be made with the period after 1990, when these two republics were within one state. When this paper was near completion, Montenegro became independent, yet it will take some time before the World Bank publishes its first official data for Serbia and Montenegro as separate states. For this reason, this paper will continue to treat Serbia and Montenegro as one country. However, Serbia's economy constitutes a much larger system than Montenegro's. For example, the Montenegro's GDP at the end of the 1980s amounted to about 5.4\% of Serbia's GDP (i.e. Serbia, together with its two regions, Voivodina and Kosovo).

From 1957 to 1988 Serbia and Montenegro maintained the largest economy among all the Yugoslav republics (and thus also the highest share in the Yugoslav GDP). Serbia and Montenegro participated with 39-40\% in Yugoslavia's GDP. This proportion did not change in about thirty years. Obviously, this ratio pertained mainly to Serbia, since Montenegro's share in producing Yugoslavia's GNP was small - more or less 2\%, while Serbia's was around $37-38 \%$. Croatia had the second largest economy in Yugoslavia; with a share in the GDP between $25 \%$ and $28 \%$. Croatia, incidentally, also showed the greatest change among all the republics in the Yugoslav period. In 1957 Croatia's participation in Yugoslavia's GDP was $28 \%$, whereas in 1988 it fell to $25 \%$. Slovenia had the third largest economy in former Yugoslavia, with a $17 \%$ share in the country's GDP. Bosnia and Herzegovina participated with nearly $13 \%$, and Macedonia with $6 \%$ of Yugoslavia's GDP. If we now divide ex-Yugoslavia into a western and an eastern half, then the West - i.e. Slovenia, Croatia, Bosnia and Herzegovina (SCBH), produced 55\% of Yugoslavia's GDP, and the East - Serbia, Montenegro and Macedonia (SMM), produced $45 \%$. The population distribution between the West and the East was about equal $-50: 50 \%$.

After the break-up of Yugoslavia and the creation of five new states; through the war and the transition period, the previously existing percentages of economic production significantly changed. To illustrate this we have presented data for the year 2000. We did not present data for the period 1990-1999, since the World Bank did not provide all the relevant statistics for Serbia and Montenegro during that decade. To be exact, such material is given for Slovenia from the beginning of the 1990s, and several years later for Croatia and Macedonia and Bosnia and Herzegovina, but most of the data for Serbia and Montenegro was published for the first time only in 2000. According to the data for 2000 and 2005, Serbia and Montenegro no longer made up the largest economy in the former Yugoslav region. The leading position has been taken by Croatia and Slovenia. Croatia's portion in the aggregate gross national income (GDI) of all the states in the former Yugoslav area had increased from 25\% (1988) to 34\% (2000) and Slovenia's from 17\% (1988) also to $34 \%$ (2000). At the same time, Serbia and Montenegro's part fell notably from $39 \%$ (1988) to $17 \%$ (2000), and Bosnia and Herzegovina's from 13\% (1988) to 8\% (2000). 
Macedonia's portion remained about the same, around 6\%. In the period 2000-2005 there was a certain economic recovery in Serbia and Montenegro and the country's share in the aggregate GDI in the ex-Yugoslav area rose from $17 \%$ to $24 \%$. If we now divide the former Yugoslav area into its western and eastern sections, i.e. into SCBH and SMM, then SCBH produced 77\% (2000) and 71\% (2005) of the region's GDI, and SMM 23\% (2000) and 29\% (2005).

\section{Size (GDP) and Development (GDP per capita) of the Economies of the Yugoslav states in 1988}

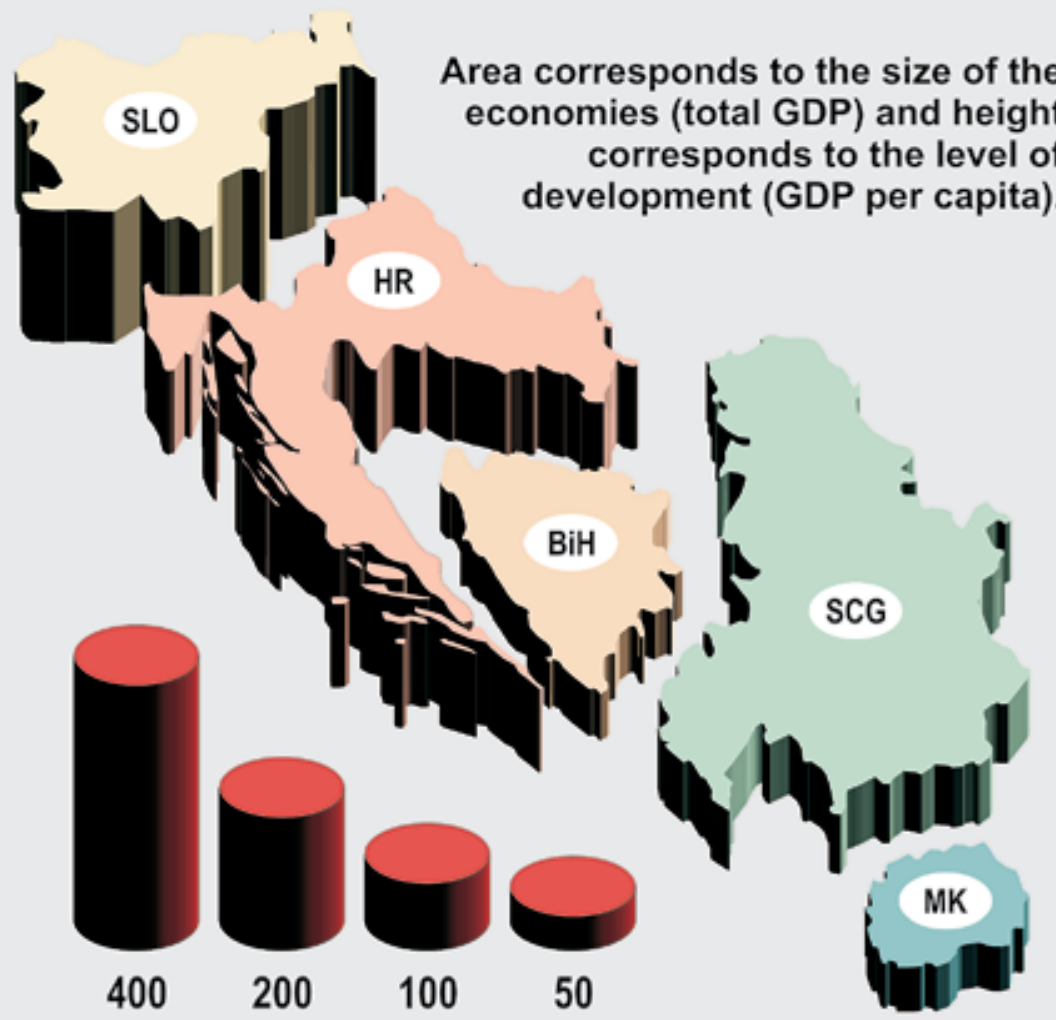

100 corresponds to the Yugoslav average

Fig.1 Size (GDP) and Development (GDP per capita) of the Economies of the Yugoslav states in 1988

Sl. 1. Veličina (GDP) i razvijenost (GDP po stanovniku) ekonomija republika u Jugoslaviji 1988. $g$. 


\section{Size (GDP) and Development (GDP per capita) of the} Economies of the ex-Yugoslav states in 2000

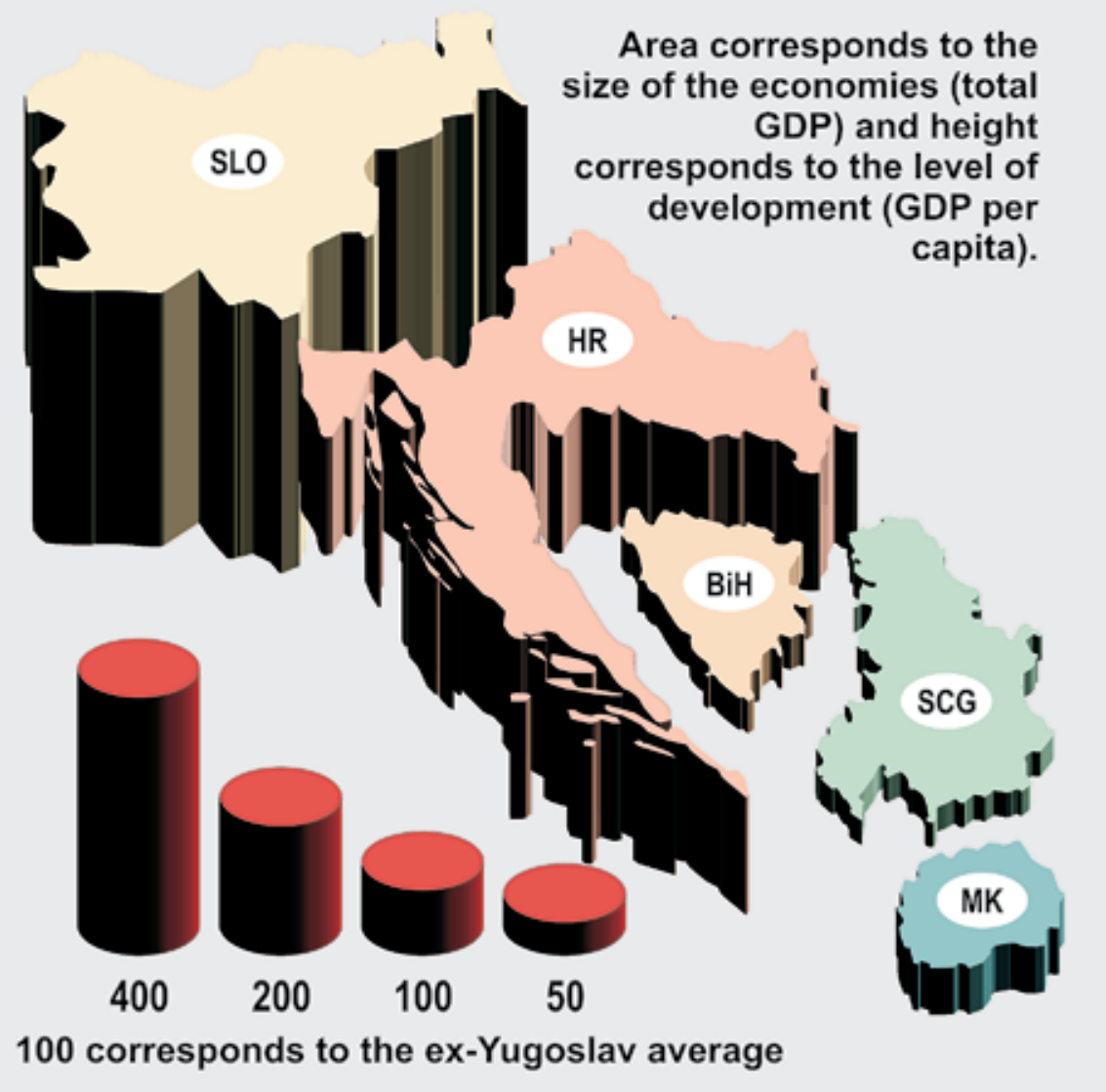

Fig. 2 Size (GDP) and Development (GDP per capita) of the Economies of the ex-Yugoslav states in 2000

Sl. 2. Veličina (GNI) i razvijenost (GNI po stanovniku) ekonomija država u bivšem jugoslavenskom prostoru 2000. $g$. 


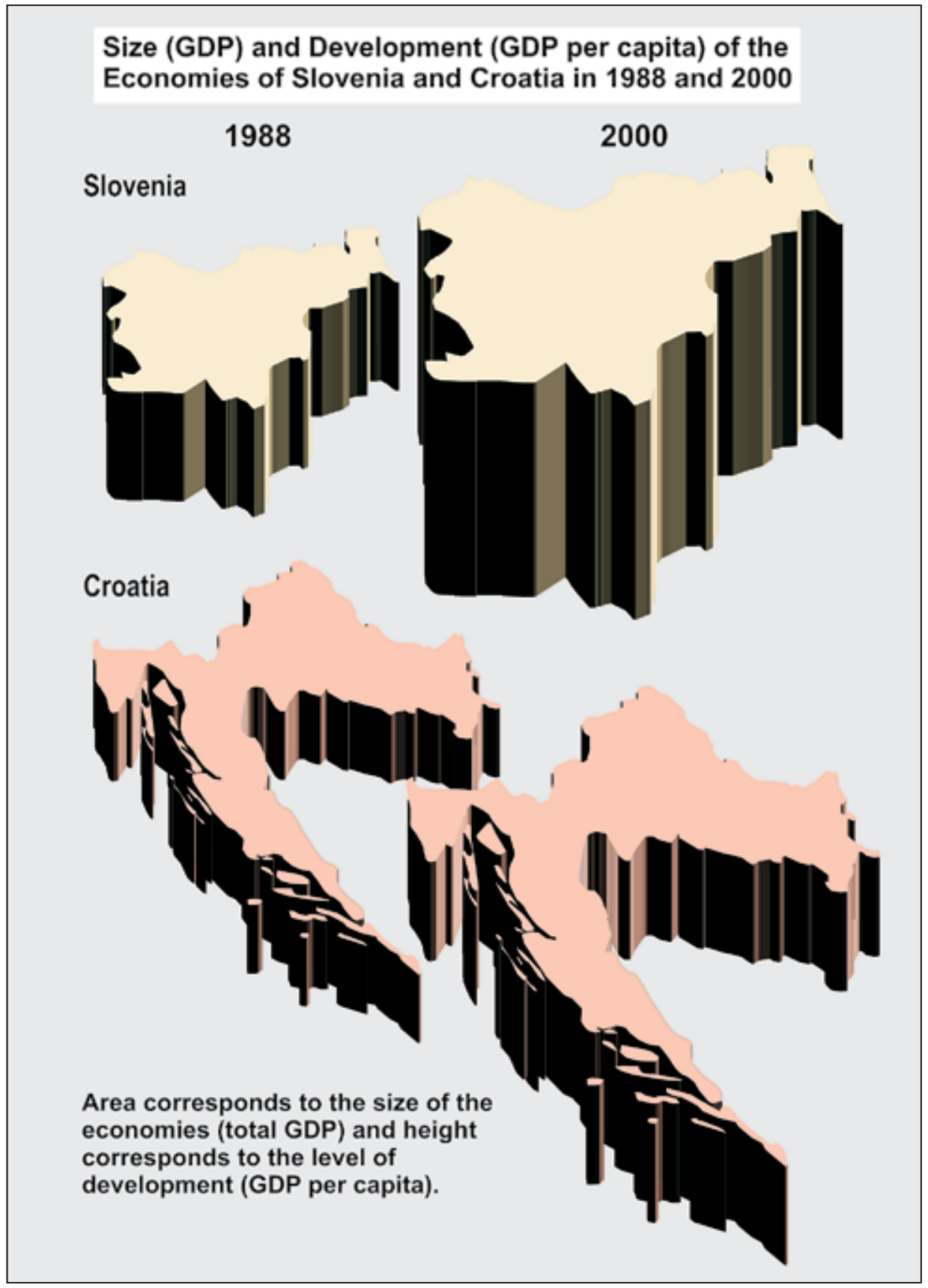

Fig. 3 Size (GDP) and Development (GDP per capita) of the Economies of Slovenia and Croatiain 1988 and 2000

Sl. 3. Veličina (GDP; GNI) i razvijenost (GDP; GNI po stanovniku) ekonomija Slovenije i Hrvatske 1988. i 2000. g. 


\section{Size (GDP) and Development (GDP per capita) of the} Economies of Bosnia and Herzegovina, Serbia and Montenegro and Macedonia in 1988 and 2000

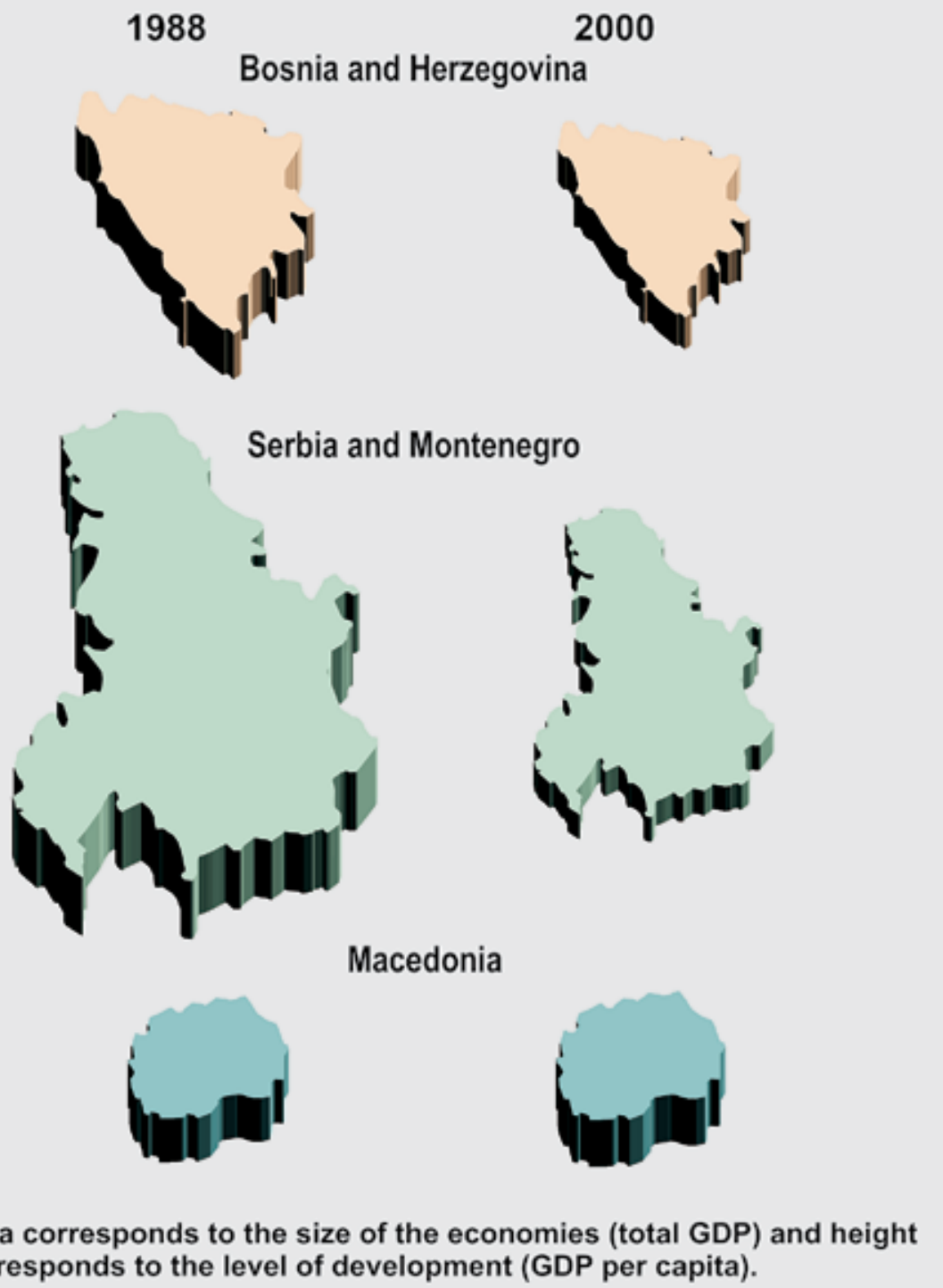

Area corresponds to the size of the economies (total GDP) and height corresponds to the level of development (GDP per capita).

Fig. 4 Size (GDP) and Development (GDP per capita) of the Economies of Bosnia and Herzegovina, Serbia and Montenegro and Macedonia in 1988 and 2000

Sl. 4. Veličina (GDP, GNI) i razvijenost (GDP; GNI po stanovniku) ekonomija Bosne i Hercegovine, Srbije $i$ Crne Gore te Makedonije 1988. i 2000. g. 
Now we will analysis levels of per capita economic development, which present a different perspective from that of absolute economic mass (i.e. share in the overall GDP).

From this perspective, traditionally the most developed republic in former Yugoslavia had been Slovenia, with a per capita gross domestic product $74-100 \%$ above the Yugoslav average in the period 1957-1988. Croatia had been the second most developed republic, with a per capita GDP 20-26\% above the Yugoslav average. All the other republics had had a per capita GDP below the Yugoslav average: Serbia and Montenegro 8-12\% below the average, Bosnia and Herzegovina 26-35\% less and Macedonia 31-38\% under the average. Certain shifts in increasing or decreasing the level of development among republics can be noticed in the period 1957-1988. Thus, an increase in the level of development is evident in Slovenia, and a slight reduction can be seen in the level of development of Bosnia and Herzegovina.

Tab. 1. Share of the republics/independent countries in Yugoslavia's GNP and in the aggregate GDI of the former Yugoslav area (1957-2005)

Tab. 1 Sudjelovanje pojedinih republika/državau Jugoslaviji/bivšijugoslavenski prostor u ukupnom društvenom proizvodu (Gross domestic product) i bruto narodnom dohotku (Gross national income) od 1957. do 2005. $g$.

\begin{tabular}{|c|c|c|c|c|c|}
\hline Year & Croatia & Slovenia & $\begin{array}{c}\text { Serbia and } \\
\text { Montenegro }\end{array}$ & $\begin{array}{c}\text { Bosnia and } \\
\text { Herzegovina }\end{array}$ & Macedonia \\
\hline \multicolumn{7}{|c|}{ During the Yugoslav period (gross domestic product, GDP) } \\
\hline 1957 & $27.9 \%$ & $14.7 \%$ & $39.5 \%$ & $12.8 \%$ & $5.2 \%$ \\
\hline 1961 & $27.2 \%$ & $16.0 \%$ & $38.9 \%$ & $13.1 \%$ & $4.7 \%$ \\
\hline 1966 & $26.4 \%$ & $15.2 \%$ & $40.2 \%$ & $12.9 \%$ & $5.2 \%$ \\
\hline 1971 & $26.8 \%$ & $16.2 \%$ & $39.3 \%$ & $12.2 \%$ & $5.5 \%$ \\
\hline 1976 & $26.1 \%$ & $16.8 \%$ & $39.5 \%$ & $12.0 \%$ & $5.6 \%$ \\
\hline 1981 & $25.9 \%$ & $16.6 \%$ & $39.6 \%$ & $12.3 \%$ & $5.6 \%$ \\
\hline 1986 & $25.0 \%$ & $16.8 \%$ & $39.5 \%$ & $12.9 \%$ & $5.8 \%$ \\
\hline 1988 & $25.5 \%$ & $16.6 \%$ & $39.4 \%$ & $12.7 \%$ & $5.7 \%$ \\
\hline \multicolumn{7}{|c|}{ After the break-up of Yugoslavia (gross national income, GNI) } \\
\hline 2000 & $34.4 \%$ & $34.0 \%$ & $17.0 \%$ & $8.3 \%$ & $6.3 \%$ \\
\hline 2003 & $32.3 \%$ & $32.2 \%$ & $21.4 \%{ }^{* *}$ & $8.6 \%$ & $5.5 \%$ \\
\hline 2004 & $32.1 \%$ & $31.2 \%$ & $23.1 \%{ }^{*} \%$ & $8.4 \%$ & $5.2 \%$ \\
\hline 2005 & $32.9 \%$ & $29.9 \%$ & $23.8 \%{ }^{* *}$ & $8.3 \%$ & $5.1 \%$ \\
\hline
\end{tabular}

* 1990-1999. Nije bilo podataka za Srbiji i Crnu Goru

** 2003-2005. Kosovo je isključeno iz Srbije i Crne Gore

Izvor: Statistički godišnjak Jugoslavije, Beograd 1989; World Development Indicators, The World Bank 
As was to be expected, a large divergence in the levels of per capita economic development occurred among the new independent states in the area of former Yugoslavia. Slovenia and Croatia became even more developed and rose further above the average level in the ex-Yugoslav area, while Serbia and Montenegro, Macedonia and Bosnia and Herzegovina moved in the opposite direction. And, so, the train composition became extremely elongated. The differences became enormous! Slovenia's per capita GNI rose to 293\% (2000) above the average in the former Yugoslav area. This was an increase from 98\% (1988) to 293\% (2000). Croatia, which had been the second most developed republic in Yugoslavia, also progressed, from $25 \%$ above the average in 1988 to $81 \%$ in 2000 . The greatest decline was experienced by Serbia and Montenegro, which had been 11\% below the average in 1988 and $63 \%$ below the average of the former Yugoslav area in 2000 . It is interesting to note that in 2000 Serbia and Montenegro became the most undeveloped country in the former Yugoslav area. Bosnia and Herzegovina also experienced a significant fall in its level of development. However, from 2000 to 2005 the overall situation in the ex-Yugoslav area reverted somewhat back to the pre-war proportions (before 1988).

Tab 2. Levels of per capita GDP/GDI of individual republics/states in regard to the Yugoslav average and the average in the area of former Yugoslavia, from 1957 to 2005

Tab.2 Razina pojedinih republika/država u Jugoslaviji/bivši jugoslavenski prostor u ukupnom društvenom proizvodu (Gross domestic product) i bruto narodnom dohotku (Gross national income) po stanovniku od 1957. do 2005. $\mathrm{g}$.

\begin{tabular}{|c|c|c|c|c|c|}
\hline Year & Croatia & Slovenia & $\begin{array}{c}\text { Serbia and } \\
\text { Montenegro }\end{array}$ & $\begin{array}{c}\text { Bosnia and } \\
\text { Herzegovina }\end{array}$ & Macedonia \\
\hline \multicolumn{5}{|c|}{ During the Yugoslav period (gross national product, GDP); Yugoslavia = 100 } \\
\hline 1957 & 122 & 174 & 90 & 74 & 67 \\
\hline 1961 & 121 & 187 & 89 & 74 & 62 \\
\hline 1966 & 120 & 179 & 92 & 72 & 67 \\
\hline 1971 & 124 & 193 & 90 & 67 & 69 \\
\hline 1976 & 124 & 199 & 90 & 65 & 68 \\
\hline 1981 & 126 & 196 & 90 & 67 & 66 \\
\hline 1986 & 123 & 200 & 89 & 70 & 68 \\
\hline 1988 & 125 & 198 & 89 & 69 & 66 \\
\hline After the break-up of Yugoslavia (gross national income, GNI); Former Yugoslav area $=100$ \\
\hline 2000 & 181 & 393 & 37 & 48 & 71 \\
\hline 2003 & 152 & 338 & $54^{* *}$ & 43 & 56 \\
\hline 2004 & 144 & 313 & $57^{* *}$ & 43 & 51 \\
\hline 2005 & 152 & 313 & $59^{* *}$ & 44 & 51 \\
\hline
\end{tabular}

* 1990-1999. Nije bilo podataka za Srbiji i Crnu Goru

** 2003-2005. Kosovo je isključeno iz Srbije i Crne Gore

Izvor: Statistički godišnjak Jugoslavije, Beograd 1989; World Development Indicators, The World Bank 


\section{Assumptions regarding recent changes}

Today there is usually limited interest as to why the period 1957-1988 remained so static, practically without any noticeable changes in the relative levels of development of the individual republics in former Yugoslavia. Therefore, we will not try to answer this question, which is of interest mostly to historians or, more precisely, to economic historians. We are more concerned with the reasons why such major changes occurred between 1990 and 2000, and in predictions regarding developments in the near future. Although no clear answers exist - certain assumptions can be made.

In the case of some (former) republics, the situation is quite obvious. Macedonia did not experience any significant changes either in the size of its economy or in its level of development relative to other countries in the ex-Yugoslav area. Hence, the Macedonian case does not require further explanation. The pronounced drop in Bosnia and Herzegovina's share in the GDP/GDI of the former Yugoslav area, and the decrease in the country's per capita level of development, was to be expected, due to the severe and devastating effects of the war in that country. The war was the main cause of this decrease. The present state of peace has installed a highly bureaucratised administration and an internal division into two (and sometimes three) separate units. International aide has stimulated passivity and a bureaucratic orientation in the population. In the Yugoslav period, a strong military industry had existed in Bosnia and Herzegovina, as well as similar economic concerns that had nurtured an intense real-socialist mentality in the workers, which had been deeply anti-entrepreneurial. Thus, the pre-war hard-line socialist structure, with the state acting as a nursemaid, was followed first by devastation, internal divisions and mistrust during the war, and later by activities on the part of the international community that created rigid bureaucratic mastodons on the local and the national level, and which through international aid increased the passivity of a milieu that had already been passive and nonentrepreneurial in the previous era. The international community, or more precisely the United Nations, has been taking care of Bosnia and Herzegovina for a long time. In order to end the war and reduce tensions the UN has established a regime of supervision in the country. UN supervision in Bosnia and Herzegovina is still in effect and the powers of UN administrators are immense, greater than the authority of all the levels of government in Bosnia and Herzegovina, including the country's central parliament, its government and presidium (which amounts to making Bosnia and Herzegovina a "protectorate"). To this should be added strong indications that a large part of the population, perhaps even the majority, does not even want the state of Bosnia and Herzegovina - but rather views other states, primarily Croatia and Serbia, as its own. This applies mostly to Croats and Serbs, but maybe also to certain segments of the Bosniak group that have been traditionally been inclined towards one or the other neighbouring country. Therefore, expecting economic success in Bosnia and Herzegovina seems quite illusive.

On the other hand, the change in the relative proportions of the three largest economies: Croatia, Slovenia and Serbia and Montenegro, is especially interesting. Slovenia and Croatia registered considerable economic growth after 1988, while Serbia and Montenegro entered into decline. Slovenia had an advantage in that it managed virtually to avoid war (the military clash between Slovene forces and the Yugoslav army at the start of Slovenia's independence lasted only a few days, and was later labelled an "operetta war", which was not only unfair, 
but also offensive, taken into consideration that there was a loss of life). Croatia, however, suffered highly from the war (after Bosnia and Herzegovina), since the war was fought on Croatian territory. Serbia and Montenegro, the state that had launched the war, likewise endured financial burdens and pressures resulting from the war, including several years of economic (and other) sanctions implemented by the international community. These sanctions also hit Macedonia, despite the country's innocence and non-involvement, since they practically closed its route to West Europe (the export route to the South was blocked by a Greek embargo, in protest to the use of the Macedonian name, and so Macedonia had for a time to rely on Bulgaria as an export outlet, which was complicated by the fact that Macedonian and Bulgarian exports to West Europe were of the same general type and therefore mutually competitive).

It is interesting to note that although Croatia was the victim of Serbian and Montenegrin aggression (as the international community generally recognised), the Croatian economy advanced, while the Serbian and Macedonia economy regressed. This should be noted as a phenomenon! Why? According to one opinion, made in the mid 1980s (when the future development in Europe could already be predicted with a high degree of accuracy) - in the expansion of market economies to the East, to the then-existing socialist world, areas that were geographically and in a civilisational sense closer to West and Central Europe would be much more successful in the new market economy than regions oriented towards the oriental-despotic Balkan zone. Subsequent events confirmed this view, e.g. if we compare the successes of Hungary and the Czech Republic on the one hand, with Bulgaria and Romania on the other hand. Thus, the more western, more "European" countries - Slovenia and Croatia, showed better results than the more eastern and more Balkanoriented countries - Serbia and Montenegro. Of course, in all the mentioned countries both types of influences exist - western, European and eastern/Balkan - the differences being in their relative intensities and prevailing tendencies. In the 1990s the government of Serbia and Montenegro was more intensely socialist and less inclined towards changes in the direction of a market economy than the Slovenian and Croatian governments. At the same time, corruption in Serbia and Montenegro was much more intense and deeplyrooted than in Slovenia and Croatia. International sanctions, as a result of the Serbia and Montenegro's hostile participation in the war, brought on further losses and furthered the country's economic deterioration. The advantages that Belgrade had had, as the capital city of former Yugoslavia, were lost. However, the most important reason that brought about this deterioration during the 1990s was probably the deep drop in the "quality" of Serbia and Montenegro's society. Slovenia managed to develop its society during this period. Moreover, Slovenia managed to replace the loss of the former Yugoslav market by redirecting its production to the market of the European Union and to other world markets. Slovenia showed a strong inclination towards a market economy, which it quickly implemented, but without typical East European rashness. It seems that Slovenia was more prepared to establish a market economy and had less elements of predatory capitalism than was usual in most, if not in all, East European countries.

What will happen in the future? No one knows the answer to this question. Nonetheless, it might be predicted that Serbia and Montenegro will develop and that their economic distance from Croatia and Slovenia will lessen, although it is doubtful whether they will 
arrive at the relative levels of development that existed during the Yugoslav period (either Serbia or Montenegro, which are now two separate countries). At present it is difficult to make such a conjecture, yet we can assume that the distance in the level of economic development between Slovenia and Croatia on the one hand, and Serbia and Montenegro on the other hand, will be greater than in the period of former Yugoslavia.

\section{b) Cooperation between the Republics/States in the Period 1957-2004}

\section{Socialist Republics as “Closed Economic Systems"}

In the former Social Federal Republic of Yugoslavia the republics existed as relatively closed economic systems, only partly linked to the economies of other republics, or to the rest of the world. It is interesting to note that in 1988 practically all outside plants of Zagreb-based industries were located within 70-80 km of Zagreb, yet in the Slovene area of Brežice, just 25-30 km from Zagreb there was not even one such outside facility from Zagreb. Thus we can conclude that the border between the Republic of Croatia and the Republic of Slovenia was very "hard" during the period of Socialist Yugoslavia. To a certain degree, in relation to Zagreb-based industries, Slovenia was another country, better said a "foreign" country, "another world", in which outside plants were not located. At this time Yugoslavia's economic system was as a whole closed, and Zagreb-based industries set up outside plants not just within Yugoslavia, but for the most part mainly in Croatia, and only to a lesser degree in other former republics and, of course, not outside of Yugoslavia.

Tab. 3. Structure of sales (sold products and services), by republics of the SFRY in 1987

Tab. 3 Struktura prodaje (prodani proizvodi i izvršene usluge) po republikama Jugoslavije 1987. g.

\begin{tabular}{|c|c|c|c|c|c|}
\hline & Total & $\begin{array}{c}\text { In the same } \\
\text { republic }\end{array}$ & $\begin{array}{c}\text { In another } \\
\text { republic }\end{array}$ & $\begin{array}{c}\text { Outside } \\
\text { Yugoslavia }\end{array}$ & Unclassified \\
\hline Yugoslavia & $100 \%$ & 67 & 22 & 10 & 1 \\
\hline Croatia & $100 \%$ & 69 & 19 & 11 & 2 \\
\hline Slovenia & $100 \%$ & 63 & 22 & 13 & 2 \\
\hline Serbia & $100 \%$ & 68 & 23 & 9 & 0,4 \\
\hline Montenegro & $100 \%$ & 60 & 27 & 10 & 4 \\
\hline $\begin{array}{c}\text { Bosnia and } \\
\text { Herzegovina }\end{array}$ & $100 \%$ & 70 & 20 & 10 & 1 \\
\hline Macedonia & $100 \%$ & 67 & 24 & 9 & 1 \\
\hline
\end{tabular}

Izvor: ZRSS, str. 8. (Privredna komora Hrvatske: Analiza odnosa gospodarstva Hrvatske s drugim republikama u Jugoslaviji, Zagreb 1991.)

During the Yugoslav period, most sales of products and services took place within the individual republics. For example, in 1987 two thirds of all sales of products and services were carried out within one and the same republic. There were no significant differences 
among the various republics. Bosnia and Herzegovina was the most closed republic in which $70 \%$ of all sold products and services took place within the republic, whereas Slovenia was the most open with a percentage of $63 \%$. These two figures indicate how small the differences were. About 1/5 of all sales took place in other republics, and 1/10 on the world market. Croatia "exported" the least to other republics (19\%), and Montenegro the most (27\%). Slovenia had the greatest share (13\%) in real exports (to countries outside Yugoslavia), and Serbia the smallest (9\%). Yet differences between the republics were small also in this case. This data confirms that the republics were relatively closed systems and that they did not participate extensively in a common "Yugoslav market", which generally accounted for only about $20 \%$ of their products and services.

\section{MARKET IMPORTANCE AND FOCUS IN THE FORMER YUGOSLAV AREA}

Among the republics, Serbia and Croatia, as the two largest economies, were also the largest markets for the republics in 1987 (in the internal Yugoslav market). Croatia was the largest market for Slovenia and Serbia, while Serbia was the largest market for the other republics. The most focused economies in turns of exports to other Yugoslav republics were Montenegro - which directed $56 \%$ of its internal Yugoslav exports to Serbia, Bosnia and Herzegovina which sent $43 \%$ of such exports to Serbia, and Slovenia which sent $46 \%$ of its internal exports to Croatia.

Tab. 4. Imports and Exports by Republics of Former Yugoslavia in 1987 (Yugoslavia = $100 \%$ )

Tab. 4 Veličina unutarjugoslavenskog izvoza i uvoza po republikama 1987. g. (Jugoslavija = $100 \%$ )

\begin{tabular}{|l|c|c|c|c|c|}
\hline & Croatia & Slovenia & $\begin{array}{c}\text { Serbia and } \\
\text { Montenegro }\end{array}$ & $\begin{array}{c}\text { Bosnia and } \\
\text { Herzegovina }\end{array}$ & Macedonia \\
\hline Imports & $22.1 \%$ & $16.8 \%$ & $41.1 \%$ & $14.4 \%$ & $5.5 \%$ \\
\hline Exports & $21.9 \%$ & $21.2 \%$ & $39.2 \%$ & $11.7 \%$ & $6.0 \%$ \\
\hline
\end{tabular}

Izvor: «Prodaja po republikah in poraba reprodukcijskega materijala v republiki Sloveniji», Zavod Republike Slovenije za statistiko, Ljubljana, februar 1991., str. 8 (Privredna komora Hrvatske: Analiza odnosa gospodarstva Hrvatske s drugim republikama u Jugoslaviji, Zagreb 1991.)

Serbia and Montenegro had a 49\% share in total Yugoslav exports, which corresponded to their share in producing the total domestic product of the country. Thus Serbia and Montenegro were the leading exporters in former Yugoslavia. If participation in producing the domestic product is compared to shares in exports, then it turns out that Slovenia was the most focused on export. Namely, Slovenia had a 21\% share in all Yugoslav exports, whereas it produced $17 \%$ of the domestic product. In the case of Croatia, on the other hand, the situation was reversed. This republic produced $26 \%$ of the Yugoslav GDP and had a $22 \%$ share in exports from Yugoslavia.

With the break-up of Yugoslavia, the importance of the former Yugoslav area as a market greatly declined, and market focuses shifted. We can see this in the case of Croatia. 
In 1987 Serbia was the most important (Yugoslav) market for Croatian exports, followed by Slovenia and by Bosnia and Herzegovina. In 2004 the situation was much different: the most important export destination was Bosnia and Herzegovina, followed by Slovenia, whereas Serbia was much less important. For example, in 1987 (considering only the internal Yugoslav market), Croatia exported 37\% of its exports to the Serbian market, $32 \%$ to the Slovenian market and 23\% to the Bosnia and Herzegovina's market. In 2004 $54 \%$ of all exports from Croatia went to Bosnia and Herzegovina, 28\% to Slovenia and $14 \%$ to Serbia and Montenegro.

Tab. 5. Most Important Export Markets within Yugoslavia for Individual Republics in 1987

Tab. 5 Najveća unutarjugoslavenska tržišta (izvoz) za pojedine republike 1987. $\mathrm{g}$.

\begin{tabular}{|c|c|c|c|}
\hline Republic & $\begin{array}{c}\text { Largest export } \\
\text { market }\end{array}$ & $\begin{array}{c}\text { Second largest export } \\
\text { market }\end{array}$ & $\begin{array}{c}\text { Third largest export } \\
\text { market }\end{array}$ \\
\hline Croatia & Serbia, 37\% & Slovenia, 32\% & $\begin{array}{c}\text { Bosnia and } \\
\text { Herzegovina, 23\% } \%\end{array}$ \\
\hline Slovenia & Croatia, $42 \%$ & Serbia, 37\% & $\begin{array}{c}\text { Bosnia and } \\
\text { Herzegovina, } 14 \%\end{array}$ \\
\hline Serbia & Croatia, 20\% & $\begin{array}{c}\text { Bosnia and } \\
\text { Herzegovina, } 16 \%\end{array}$ & Slovenia, 13\% \\
\hline Montenegro & Serbia, 56\% & Bosnia and & Croatia, 11\% $\%$ \\
\hline $\begin{array}{c}\text { Bosnia and } \\
\text { Herzegovina }\end{array}$ & Serbia, 43\% $\%$ & Croatia, 31\% $\%$ & Slovenia, 17\% \\
\hline Macedonia & Serbia, 27\% & Croatia, 19\% & Slovenia, 14\% \\
\hline
\end{tabular}

Izvor: ZRSS, str. 9. (Privredna komora Hrvatske: Analiza odnosa gospodarstva Hrvatske s drugim republikama u Jugoslaviji, Zagreb 1991.)

Besides the shift in market focusing, it should be noted that the area of former Yugoslavia generally became less important as a market for Croatian exports in 2004, than it had been in 1987 . In 1987 Croatia had sent $37 \%$ of its exports abroad and $63 \%$ to Yugoslav markets, whereas in $200473 \%$ of all Croatian exports went to other parts of the world and $27 \%$ to countries in the former Yugoslav area. These percentages suffice to illustrate that the former Yugoslav area - although still an important market for Croatia, was much less important than the Yugoslav market had been in 1987. The trends from 1999 to 2004 indicate an increase in trade between Croatia and other ex-Yugoslav countries: Bosnia and Herzegovina, Slovenia and Serbia and Montenegro. Between 1999 and 2004 there was also an increase in trade with distant Macedonia, although to a lesser degree. Nevertheless, despite this quick increase in trade between the countries of former Yugoslavia, it is difficult to imagine that exports and imports between former Yugoslav countries will ever assume the same importance as they had in the internal Yugoslav context in 1987. Other foreign markets are still much more important. For example, the largest markets for Croatian exports in 2004 were Italy (23\%), Bosnia and Herzegovina (14\%) and Germany (11\%) and the largest import markets were Italy (17\%), Germany (15\%) and Russia (7\%). 


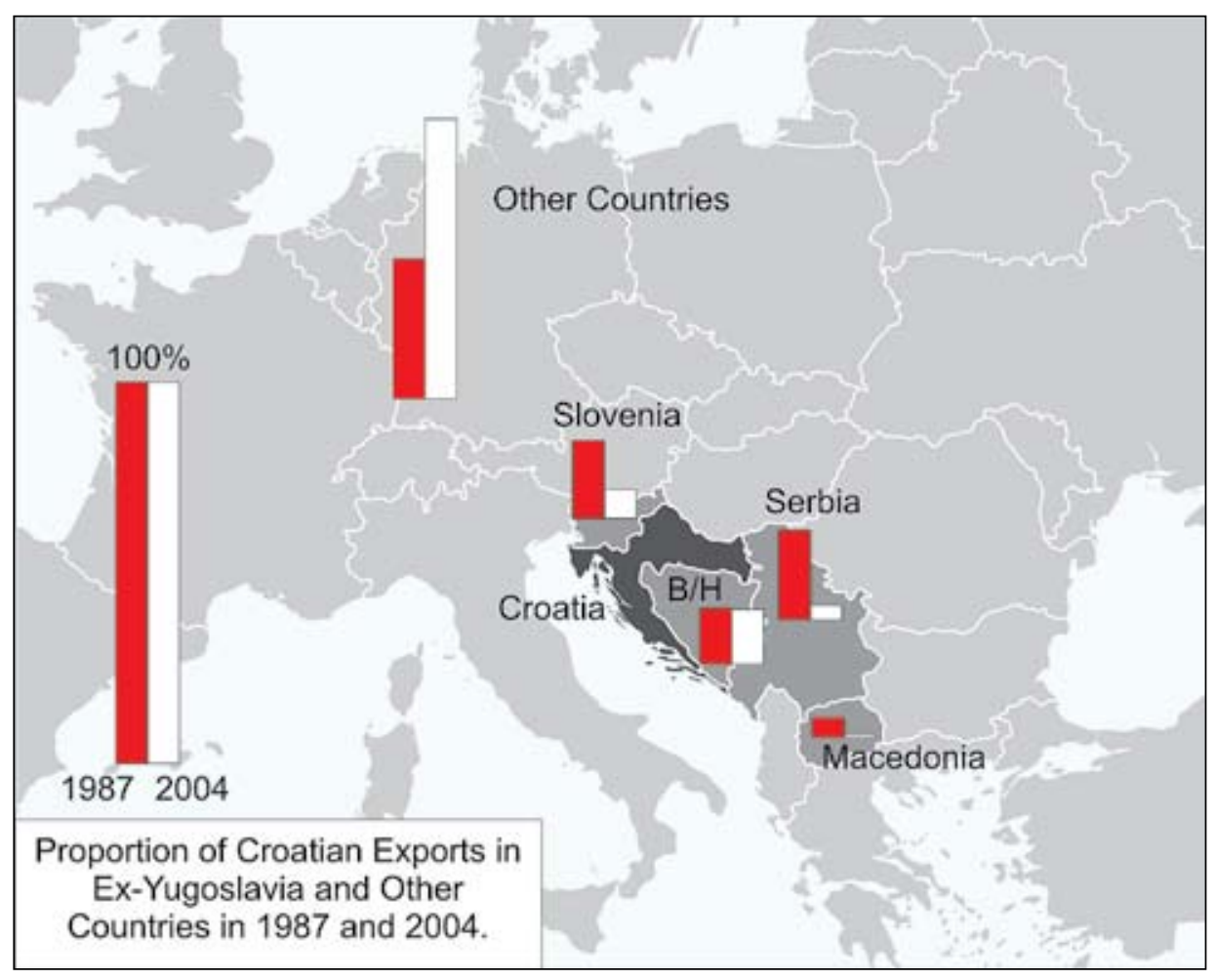

Fig. 5. Proportion of Croatian Exports in Ex-Yugoslavia and Other Countries in 1987 and 2004

Sl. 5 Udjel hrvatskog izvoza na područje bivše Jugoslavije i druge zemlje 1987. i 2004. g.

Bosnia and Herzegovina is the second most important market for Croatian exports. Two reasons seem to account for this. First, Croats in Bosnia and Herzegovina are traditionally the main buyers of products from Croatia. As we mentioned previously, many Croats in Bosnia and Herzegovina perceive Croatia as their homeland, some even as their primary homeland, others at least as their second homeland (i.e. patria seconda), and the purchase of products from Croatia would appear to confirm such a conclusion. To this we might add that many ethnic Croats have become important merchants in Bosnia and Herzegovina, and they have a personal say in what goods they will display on the shelves of their shops. For example, in Central Bosnia, where the population has a mixed Croat-Bosniak ethnic structure, many of the leading merchants are Croats. On the other hand, Croatia is more developed than Bosnia and Herzegovina, and Croatian firms are more advanced than those in Bosnia and Herzegovina, and therefore buyers from the other two ethnic groups in Bosnia and Herzegovina have a relatively good opinion of products from firms in Croatia. This opinion is often better than their opinion of their own Bosnian-Herzegovinian products. When discussing exports from Croatia or Serbia to Bosnia and Herzegovina we must always consider the importance that indigenous diasporas, Croats and Serbs, have in this trade, 
or rather the influence that their ethnicity and inclination towards their second homelands has on their choices to buy merchandise from Croatia or Serbia.

Increasing trade between independent countries in the area of former Yugoslavia is burdened by political tensions and memories of the recent war. It is very probable that images of the previous Serbian aggression against Croatia continue to block the growth of Serbian imports to the Croatian market. Memories of the war are still fresh and for many Croatian consumers are the main reason why they do not wish to buy goods from Serbia. For example, Croats buy cars made in various parts of the world, but purchases of the Serbian-made Yugo are very rare, even though this automobile is quite inexpensive. True, it is technologically inferior, yet it was nonetheless a popular vehicle in the socialist period. In fact, during the socialist period automobiles made in Serbia dominated on the Croatian market - mainly due to low prices and weak competition in the essential price ranges. Today competition on the market for low-priced automobiles is much stronger than it was prior to 1990, and Croats prefer to buy inexpensive cars from Romania, Russia and South Korea, rather than from Serbia. One of the reasons is a more secure market, but it is highly likely that aversion towards goods from Serbia, as a result of memories of the war, also has a certain effect. Namely, today it is practically bad-mannered to buy a Serbian automobile in Croatia.

Tab. 6. Trade in Goods between Croatia and Other States in the Former Yugoslav Area in the Period 1994-2004 (in millions of US\$)

Tab. 6 Robna razmjena Hrvatske s državama s bivšega jugoslavenskog prostora, 1999. i 2004. (u mil. USD)

\begin{tabular}{|c|c|c|c|c|}
\hline & Export & Import & Total & Balance \\
\hline \multicolumn{5}{|c|}{1999} \\
\hline Slovenia & 454 & 616 & 1070 & -162 \\
\hline $\begin{array}{l}\text { Bosnia and } \\
\text { Herzegovina }\end{array}$ & 547 & 117 & 664 & 430 \\
\hline Macedonia & 64 & 52 & 116 & 12 \\
\hline $\begin{array}{l}\text { Serbia and } \\
\text { Montenegro }\end{array}$ & 27 & 24 & 51 & 3 \\
\hline TOTAL & 1092 & 809 & 1901 & 283 \\
\hline \multicolumn{5}{|c|}{2004.} \\
\hline Slovenia & 601 & 1179 & 1780 & -578 \\
\hline $\begin{array}{l}\text { Bosnia and } \\
\text { Herzegovina }\end{array}$ & 1154 & 349 & 1503 & 805 \\
\hline $\begin{array}{l}\text { Serbia and } \\
\text { Montenegro }\end{array}$ & 294 & 141 & 435 & 153 \\
\hline Macedonia & 74 & 117 & 191 & -43 \\
\hline TOTAL & 2123 & 1786 & 3909 & 337 \\
\hline
\end{tabular}

Izvor: Državni zavod za statistiku Republike Hrvatske

Obrada: Hrvatska gospodarska komora, Sektor za međunarodne odnose 
Tab. 7. Trade in Goods between Slovenia and Croatia (1995-2003, millions of US\$)

Tab. 7 Robna razmjena Slovenije i Hrvatske (1995-2003., mil USD)

\begin{tabular}{|c|c|c|c|c|c|}
\hline Year & Export & Import & Total & $\begin{array}{c}\text { Share in total } \\
\text { Slovenian exports, } \\
\text { \% }\end{array}$ & $\begin{array}{c}\text { Share in total } \\
\text { Slovenian imports, } \\
\%\end{array}$ \\
\hline 1995 & 891 & 576 & 1467 & 10.7 & 6.1 \\
\hline 1996 & 855 & 590 & 1445 & 10.3 & 6.3 \\
\hline 1997 & 837 & 466 & 1303 & 10.0 & 5.0 \\
\hline 1998 & 815 & 431 & 1246 & 9.0 & 4.3 \\
\hline 1999 & 671 & 444 & 1115 & 7.9 & 4.5 \\
\hline 2000 & 688 & 448 & 1136 & 7.9 & 4.0 \\
\hline 2001 & 799 & 404 & 1203 & 8.6 & 3.6 \\
\hline 2002 & 902 & 397 & 1299 & 8.7 & 3.6 \\
\hline 2003 & 1142 & 504 & 1646 & 8.9 & \\
\hline
\end{tabular}

Izvor: Statistički ured Republike Slovenije, listopad 2004.

If we look at trade in goods between Croatia and Slovenia, then we will see that the importance of the Croatian market for Slovenian exports decreased between 1995 and 2000, and afterwards began to increase once more. From the regional perspective, Croatia carried out most of its exports (41\%) and imports (34\%) with countries in its near vicinity: Italy, Austria, Slovenia and Hungary. Countries in the Stability Pact for South-East Europe (in the so-called West Balkans), were much less important trade partners for Croatia: accounting for only $19 \%$ of all Croatian exports and $4 \%$ of all imports. As for Slovenia, in 2003, for example, this country exported $66 \%$ of the total value of its exports to the European Union, and $17 \%$ to South-East Europe. Within this framework, Slovenia exported $23 \%$ of its total exports to Germany and $9 \%$ to Croatia.

In conclusion, we may presume that the recent jump in trade between countries in the area of former Yugoslavia is a short-term trend, resulting from the elimination of barriers that for a long time had hindered mutual free trade. However, it is likely that this development will soon arrive at a point of saturation, and that the basic focus will continue to target the neighbouring West European regional market and other world markets.

A second key indicator of economic activities between countries in the area of former Yugoslavia are direct foreign investments. In Croatia most foreign investments have come from Austria (26\%), Germany (18\%) and the US (12\%). From countries in the former Yugoslav area, the most foreign investments in Croatia have come from Slovenia, although they have a relatively small share in the total number (3.8\%). On the other hand, most Croatian investments abroad have been directed to Switzerland (37\%), Bosnia and Herzegovina (15\%) and Serbia and Montenegro (11\%). From this we may conclude that 
Zoran Stiperski, Jelena Lončar - Changes in Levels of Economic Development among the States Formed in the Area of Former Yugoslavia

countries in the area of former Yugoslavia are fairly weak economically and cannot compete with regional and global economic giants, although Croatian investors do occasionally decide to invest in neighbouring countries that are less developed than Croatia: Bosnia and Herzegovina and Serbia and Montenegro.

Tab. 8. Croatia's Most Important Foreign Trade Partners in the Region in 2004

Tab. 8 Najvažniji vanjskotrgovinski partneri Hrvatske 2004. g. u regiji

\begin{tabular}{|c|c|c|}
\hline \multirow[b]{2}{*}{$\begin{array}{c}\text { Countries of the Stability Pact (or the } \\
\text { West Balkans) }\end{array}$} & \multicolumn{2}{|c|}{ In Millions of US\$ } \\
\hline & EXPORT & IMPORT \\
\hline Bosnia and Herzegovina & 1.154 & 349 \\
\hline Serbia and Montenegro & 294 & 141 \\
\hline Macedonia & 74 & 117 \\
\hline Albania & 27 & 1 \\
\hline Total & $1.549(19 \%)$ & $608(4 \%)$ \\
\hline \multicolumn{3}{|l|}{ Other countries in the vicinity } \\
\hline Italy & 1.834 & 2.819 \\
\hline Austria & 757 & 1.131 \\
\hline Slovenia & 601 & 1.179 \\
\hline Hungary & 103 & 509 \\
\hline Total & $3.295(41 \%)$ & $5.638(34 \%)$ \\
\hline \multicolumn{3}{|l|}{ The broader economic environment } \\
\hline Germany & 895 & 2.569 \\
\hline Russia & 115 & 1.206 \\
\hline Czech Republic & 50 & 396 \\
\hline Poland & 42 & 282 \\
\hline Romania & 69 & 190 \\
\hline Slovakia & 27 & 155 \\
\hline Bulgaria & 28 & 51 \\
\hline Greece & 15 & 53 \\
\hline Total & $1.241(15 \%)$ & $4.902(30 \%)$ \\
\hline Total environment & $6.085(76 \%)$ & $11.148(67 \%)$ \\
\hline Total from/to Croatia & $8.022(100 \%)$ & $16.583(100 \%)$ \\
\hline
\end{tabular}

Izvor: Državni zavod za statistiku, obrađeno u Hrvatskoj gospodarskoj komori

Agrokor, the largest privately-owned Croatian corporation, has intentions of becoming a major regional corporation, and in accordance with this goal has been buying companies and forming partnerships, for example, in Serbia and in Bosnia and Herzegovina. On the other hand, Agrokor has likewise established ties with the European Bank for Reconstruction and Development. Some Croatian firms feel that it is easier to operate on the regional market, rather than on the West European or the world market, and for this reason they have 
been developing themselves as regional firms, instead of striving to become European or international companies. There are, of course, exceptions to this trend, such as Podravka, a Croatian firm that has attained global significance through its strategic product "Vegeta", sold in over 40 countries throughout the world.

\section{ORIENTATION TOWARDS THE WEST AND THE EUROPEAN UNION}

The most developed countries in the area of former Yugoslavia are distinctly oriented towards the West. In the case of Croatia this is can be seen if we examine the frequency of border crossings. Most travellers cross Croatia's borders with Slovenia (53\%) and with Bosnia and Herzegovina (36\%). Relatively few crossings occur in the East, over the border with Serbia and Montenegro (6\%). Thus we can conclude that a strong spatial orientation exists towards the West - towards the more modernised and developed part of Europe. Of course, almost the entire overland tourist flow arrives via Slovenia and Hungary. The frequency of border crossings with Bosnia and Herzegovina is also high, due to the fact that Croatia is Bosnia and Herzegovina's gateway to the West, and in general an exit route for Bosnia and Herzegovina, as is evident from the geographic position of the two countries: Croatia envelops Bosnia and Herzegovina on three sides. Croats from Bosnia and Herzegovina, who have more intense transactions with Croatia, likewise increase border traffic. Also, the shortest route from Slavonia (North-East Croatia) to Dalmatia (South-East Croatia) goes through Bosnia and Herzegovina (as does air traffic from Zagreb to Dubrovnik). Border traffic between Croatia and Serbia and Montenegro is, on the other hand, surprisingly weak, accounting for only $6 \%$ of all border crossings into and out of Croatia.

A second example is Slovenia and its rhythm of motorway construction. Slovene first built the route Slovenica, for the purpose of connecting Maribor, Celje, Ljubljana and the Slovenian coast. In the second phase, motorways were built in the direction of Slovenia's western or northern neighbours: Italy, Austria and Hungary. Motorways to Croatia were not constructed in this phase. It is interesting to note that Slovenica (Maribor-Celje-Ljubljanathe Slovene coast) is more oriented towards the Italian city of Trieste, than towards the Slovene port of Koper. This was the result of strong Italian demands, yet it was also due to the logic of building the European motorway network. Namely, Slovenica will become part of the European route connecting the Hungarian capital, Budapest, with the Italian North (Trieste, Milano, etc.). In the third phase, Slovenia began to build motorways also in the direction of Croatia, in order to link the two capitals: Ljubljana and Zagreb. There are two reasons for this: 1) the Slovenian capital required an eastern exit, and 2) there were strong demands from the local community in Novo Mesto (the Slovenian town located halfway between Ljubljana and Zagreb). To be exact, a large part of Slovenia, the entire Dolenjsko region, is located between Ljubljana and Zagreb, and since motorways were not built in this direction, this part of Slovenia suffered disadvantages. The strength of the lobby in Novo Mesto was an additional reason for beginning the construction of the motorway Ljubljana-Zagreb. To be precise, there is a Renault assembly plant in Novo Mesto, in which Renault's popular Twingo model is assembled, which is why Novo Mesto has become Slovenia's leading industrial exporter. This was a key reason and the force 
behind initiating the construction of the motorway, which will bring Novo Mesto out of isolation and secure its development. However, the construction of two other motorway links, important for Croatia, has not yet begun: i.e. construction of the Slovenian sections in the route from Graz (Austria) via Maribor (Slovenia) to Zagreb (Croatia), and in the route from Trieste (Italy) via Koper (Slovenia) to Rijeka (Croatia). These links between Croatia and Italy and Croatia and Austria pass through small parts of Slovenia (with weak local lobbies), yet they would considerably open up Croatia. The European Union has recently made demands on Slovenia to commence construction of these pieces of motorway (especially along the Graz-Maribor-Zagreb route), which would connect the EU to Croatia. Namely, these small sections in Slovenia constitute breaks in the European network of motorways towards the South-East: to Croatia, and further on to Bosnia and Herzegovina, Serbia and Montenegro and finally to Greece.

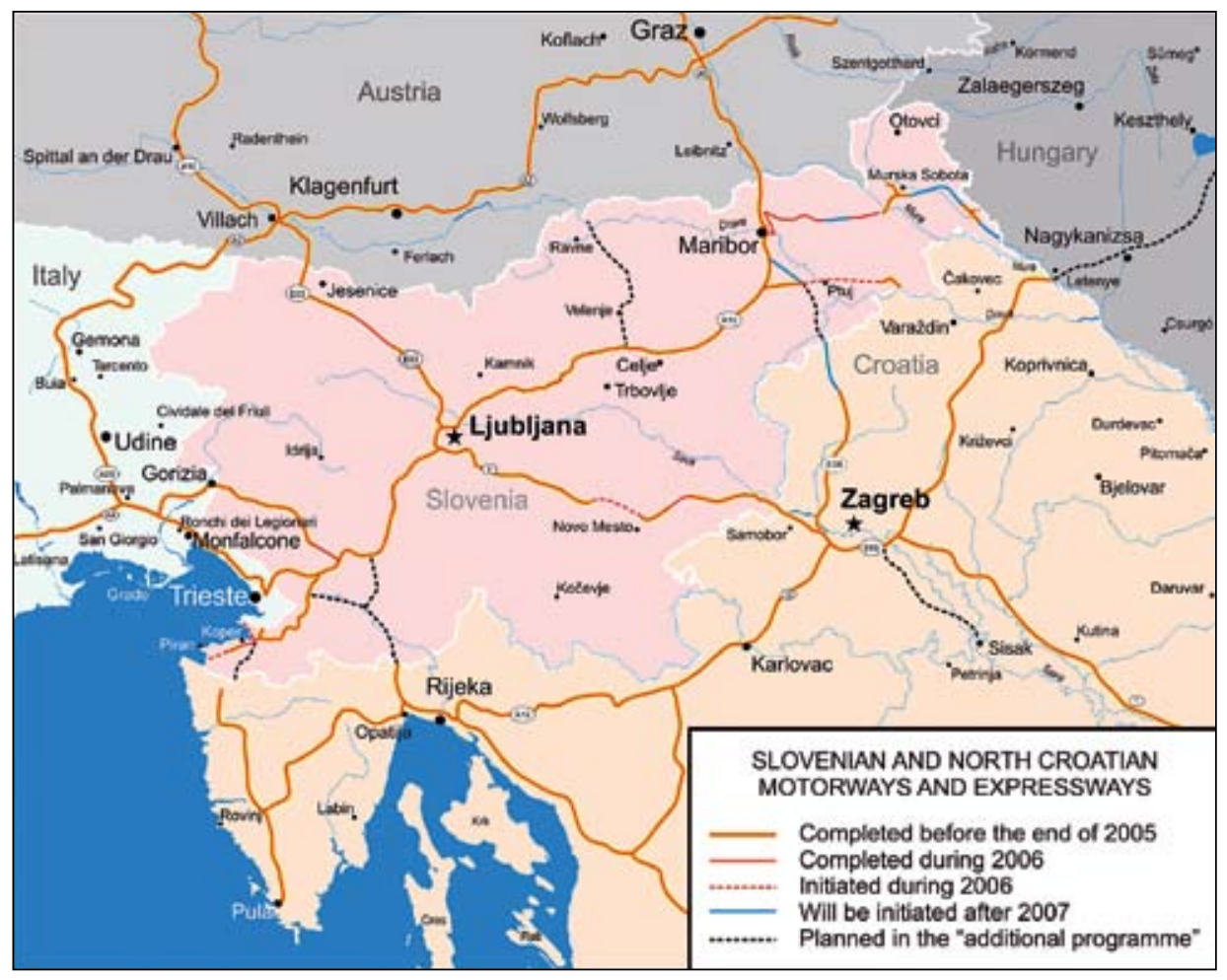

Fig. 6. Slovenian and North Croatian Motorways and Expressways

Sl. 6 Slovenska i sjeverozapadna hrvatska mreža autocesta i magistralnih cesta 
We may add that with the fall of the Berlin Wall in 1989 and after the bloody disintegration of Yugoslavia very important changes occurred in the directions of major traffic routes in this part of Europe. As long as the "Iron Curtain" had existed, the main traffic route connecting West Europe to Istanbul and the Near East had passed through Vienna, Zagreb, Belgrade and Skopje. However, when the "Iron Curtain" was removed, this route reverted back to its natural course along the Danube, from Vienna to Budapest, Belgrade and Sofia, by-passing Zagreb and Skopje. Thus Zagreb lost importance as a point of transit. Yet the disappearance of the "Iron Curtain" opened up several new and interesting European routes. Thus a virtually straight line of communication now links the Mediterranean, from Rijeka, via Zagreb and Budapest, to Kiev in the Ukraine and to locations further in the East. Another virtually straight line connects the North Sea/Baltic with the Adriatic, from Copenhagen, via Berlin, Prague, Vienna and Zagreb, to Rijeka. Finally, there are plans to develop the Adriatic-Ionian route, which will link Croatia with Greece, through Montenegro and Albania.

As a third example of orientations, we looked at the frequency of articles dealing with the European Union and the region (i.e. the area of former Yugoslavia) published in three important daily papers in Croatia, Slovenia and Serbia and Montenegro, in October and November 2005. It is interesting to note that according to this indicator Croatia, in comparison to Slovenia and Serbia and Montenegro, was more oriented towards the European Union (72\%), than towards the region (former Yugoslavia) (28\%). On the other hand, in Slovenia, although it is now a member of the EU, there were more articles on the region (former Yugoslavia) (59\%), than on the European Union (41\%). In Serbia and Montenegro $55 \%$ of the published articles dealt with the European Union and $45 \%$ with the region (former Yugoslavia).

\section{CONCLUSION}

1. Differences in the levels of economic development have increased in the area of former Yugoslavia

- Differences in size (in gross domestic product, GDP) have significantly increased between the three largest economies in the area of former Yugoslavia: Croatia, Slovenia and Serbia and Montenegro.

- The difference between Slovenia, the most developed republic/country (based on per capita GDP), and the less developed republics/countries, has considerably increased from the time of Yugoslavia to the present.

2. The centre of economic development has distinctly shifted towards the West

- Croatia and Slovenia are now the two largest economies; Serbia and Montenegro make up the third largest economy, yet in 1987 the Serbian-Montenegrin economy had been the largest in Yugoslavia (with a 40\% share in the country's GDP).

- SCBH (Slovenia, Croatia, Bosnia and Herzegovina) previously produced 55\% of Yugoslavia's total GNI (1987), whereas today (2005) this area produces $71 \%$ 
of the aggregate GNI in the area of former Yugoslavia. Slovenia and Croatia, taken together, produced $43 \%$ of the area's GNI in 1987 and $63 \%$ in 2005.

3. Trade has weakened in the area of former Yugoslavia

- Trade connections between countries in the former Yugoslav area are much weaker today than they were in the Yugoslav period. Recently trade between these countries has increased, but its intensity is still weaker than in the Yugoslav period.

- After the break-up of Yugoslavia, neighbouring states (Germany, Italy) became the main foreign trade partners of the former Yugoslav republics (newly independent states).

\section{Various economic systems}

- During the Yugoslav period, the constitutive republics had been quite separate economic systems. Namely, about $60 \%$ of all goods and services were sold within the individual republics, about $20 \%$ in other republics, and only $10 \%$ abroad. Consequently the ties between republics in Yugoslavia had been much weaker than ties between the Soviet republics in the USSR. The Soviet republics in the USSR had been much more dependent on Russia, than former Yugoslav republics had been on Serbia. The reason was that Russia produced about $75 \%$ of the USSR's total GNI, whereas Serbia produced only $37 \%$ of Yugoslavia's GDI. Moreover, Serbia had much smaller capacities to impose on-going processes and a strategic dependence on itself in the other republics, in comparison to Russia's position in the Soviet Union. The Soviet Union, indeed, had developed on the basis of the Russian Empire, which had experienced at least three centuries of continuity, economic integration and the diffusion of modernisation models through Russian centres. In contrast, Yugoslavia came into being as an artificial make-shift state with no historical basis, in which Serbia was on a lower level of development in comparison to Croatia and Slovenia, and therefore could not carry out any modernisation role, but instead imposed a parasitic model of domination.

- The differences between the economic systems of the various republics, based on their levels of development, became even greater after gaining independence.

- The differences in the levels of development are large. If we compare average earnings: Slovenia has convincingly the highest average salary (around 1200 $€)$, twice as high as Croatia (600 €) and several times greater than Serbia and Montenegro (170 €). Slovenia is on the threshold of becoming a highly developed West European country. Croatia is in the middle, between the high level of development in West Europe and the low level, prevalent in South-East Europe and on the Balkans. The other states, Serbia and Montenegro, Bosnia and Herzegovina and Macedonia show a low level of development, typical for South-East Europe and the Balkans. Thus, in the area of former Yugoslavia totally different economic worlds exist, with different orientations and concerns. The same economic models cannot be applied in all parts of the former Yugoslav region. 


\section{DISCUSSION}

1) Is it realistic to expect (in the near future) a return to the relative levels of development that characterised Slovenia, Croatia and Serbia and Montenegro during Yugoslavia period (before 1990)? Or, in other words, will there be a reduction of the differences in their levels of development, bringing them back to their 1957-1987 proportions? We believe that a return to the situation of 1987 is not possible. There are several reasons for this:

- The wheels of history can practically never be turned back.

- During the Yugoslav period, there was a constant mixture of influences in the "Yugoslav pot" and a certain equalisation of ideas and policies took place. After 1990 this stopped. Namely, many advanced economic incentives had previously passed from SMBH to SMM. Such modernisation forces no longer exist. Tendencies towards modernisation, expanding from the West to the East and to the undeveloped parts of the former Yugoslav area, can be expected only after the establishment of a closer association with the European Union and finally after EU membership, yet this will not occur in the next decade or so.

- Countries nearer to West and Central Europe, such as the Czech Republic, Poland and Hungary, have demonstrated greater economic success than more distant countries, such as Romania, Bulgaria and the Ukraine. The same applies in the area of former Yugoslavia, where Slovenia and Croatia - closer to West and Central Europe - have had more success with market economies than more distant Bosnia and Herzegovina, Serbia and Montenegro and Macedonia.

- If we examine the state of development in the area of former Yugoslavia before the creation of the first Yugoslav state in 1918, than it is evident that the western lands that had been part of the Habsburg monarchy had been much more developed than the Kingdom of Serbia (which at the time also included Macedonia). For example, immediately before WWI, Zagreb was convincingly the strongest banking centre, with the largest bank capital, in the entire former Yugoslav area.

2) Can we expect a strengthening of ties between countries in the former Yugoslav area, to the level of intensity that existed prior to 1990 ? We believe that cooperation in trade will continue to develop, but that its level of intensity, and especially dependency, will not arrive at the pre-1990 levels. There are several reasons for this:

- The main orientation of these countries is towards West Europe. This is especially obvious in the case of the more developed countries, Slovenia and Croatia. Slovenia's and Croatia's main foreign trade partners are located in West Europe. At any rate, if a former republic wishes to develop, then the former Yugoslav market is too small and it is important to be active on the West European and on other world markets.

- During the entire period from 1990 until the present there was never a break in normal trade relations between Croatia and Slovenia. The value of this trade 
increased, but its share in total trade decreased. Therefore, the importance of the Croatian market for Slovenian producers of goods and services has diminished.

- Some ideas have been expressed on the possibilities of establishing an economic association between some, or even all the countries in the area of former Yugoslavia. So far, however, no such idea is close to realisation. One concept advocated the development of an arms industry in the former Yugoslav area, yet to this point no one has been able to launch such a project. The government of former Yugoslavia had previously pursued a policy in which no plant or republic could manufacture serious armaments by itself. Just before the war and the break-up of Yugoslavia, some plants had been transferred to Serbia, but a serious penetration of foreign markets would require a return to previous forms of cooperation. Before the war $40 \%$ of the arms industry had been located in Bosnia and Herzegovina, and the rest mainly in Serbia, Croatia and Slovenia. The value of yearly production had amounted to 1.8 billion US\$, and of yearly exports to 700 million US\$. The main foreign markets had been Iraq (41\%), the Soviet Union (23\%) and Egypt $(8 \%)$.

- In the case of Croatia, one important aspect of the country's industrial structure is not compatible with the notion of closer economic association in the area of former Yugoslavia. Namely, Croatia's largest single industry is shipbuilding, and not one of the countries in the former Yugoslav area is potentially an important client for this industry.

\section{REFERENCES}

Alkalaj, S., 2002: Globalization and economic diplomacy: new challenge for Bosnia and Herzegovina. Diplomatic Academy year book, International conference "Economic diplomacy in countries in transition", Sarajevo, p. 30-35.

Bogoev, K. (editor), 1994: Ekonomska tranzicija: sostojbi, problemi, perspektivi. Makedonska akademija na naukite i umetnostite, Skopje, p. 325.

Cicvarić, A., 1992: Korijeni i recidivi dogovorne ekonomije. Ante Cicvarić, Zagreb, p. 84.

Dinkić, M., 2000: Ekonomija destrukcije: velika pljačka naroda. Stubovi kulture, Beograd, p. 314

Kljusev, N., et al, 2002: Ekonomijata na Makedonija vo tranzicija: problemi, dilemi, celi. Makedonska akademija na naukite i umetnostite, Skopje, p. 340.

Lang, R., Macesich, G., Vojnić, D. (editors), 1982: Essays on the political economy of Yugoslavia. Informator, Zagreb, p. 371

Lalović, D., 2002: Crnogorska država pred izazovom budućnosti. Međunarodne studije = International studies: časopis za međunarodne odnose, vanjsku politiku i diplomaciju. Zagreb, p. 34-46.

Lorber, L., 2005: The influence of EU enlargement process on structural changes of Slovenia's economy. Erwartungen und erste Ergebnisse der EU-Erweiterung, (Arbeitsmaterialien zur Raumordnung und Raumplanung, 238). Tagung des Forschungssechsecks der Universitäten Bayreuth, Bratislava, Graz, Maribor, 
Pécs und Plzen, im Schloss Thurnau, am 22. April 2005. Bayreuth: Lehrstuhl Wirtschaftsgeographie und Regionalplanung, Universität, 2005, p. 39-55

Lorber, L., 2005: Slovenia's changed geographical - economical position in comparison with neighbouring countries after 1991. Problemi regionalnog razvoja Hrvatske i susjednih zemalja, zbornik radova, Zagreb, 28.-30. studenoga 2002., Hrvatsko geografsko društvo. Zagreb, p. 97-108

Mrak, M., 2000: Communal infrastructure in Slovenia: survey of investment needs and policies aimed at encouraging private sector participation. World Bank technical paper. Europe and Central Asia poverty reduction and economic management series; No. 483, The World Bank, Washington, D. C., LVI, p. 59.

Mrak, M., Rojec, M., Silva-Jauregui, C., 2004: Slovenia: from Yugoslavia to the Eastern Union. The World Bank, Washington, D. C., LVI, p. 446.

Radonjić, R., 2001.: Crna Gora danas: unutarnje stanje i međunarodni položaj. Međunarodne studije = International studies: časopis za međunarodne odnose, vanjsku politiku i diplomaciju. Zagreb, p. 13-24.

Rohatinski, Ž., 1991: Privredna kretanja na prijelazu u godinu 1991. i mjere ekonomske politike. Ekonomski pregled, Hrvatsko društvo ekonomista Zagreb, Zagreb, p. 101-114.

Stropnik, N., Stanovnik, T., 2002: A case study of Slovenia, Vol. 2., Ljubljana, p. 112.

Uzunov, N., 2001: Stopanstvoto na Republika Makedonija: 1945-1990. Makedonska akademija na naukite i umetnostite, Skopje, p. 387.

Vacić, A., 1988: Ekonomska politika Jugoslavije: opšta pitanja ekonomske politike. Savremena administracija, Beograd, p. 381

Vlahović, M., 2001: Democratic Montenegro as a factor for peace in the Balkans. National security and the future, Zagreb, p. 107-110.

Vojnić, D., 1990: Ekonomska znanost i pluralističke reformske opcije. Savjetovanje jugoslavenskih ekonomista "Aktualni problemi privrednih kretanja i ekonomske politike Jugoslavije. Ekonomski pregled, Hrvatsko društvo ekonomista Zagreb, Zagreb, p. 59-64.

Vučić, P., 1990: Što je to nacionalna ekonomija? Ekonomski analitičar: časopis orijentiran upravljanju, Zagreb, p. $44-48$.

Vukičević, S., 2003: Crna Gora na prelazu milenijuma. Centralna narodna biblioteka Republike Crne Gore "Đorđe Crnojević", Cetinje, p. 331.

\section{SOURCES}

Statistički godišnjak Jugoslavije, Belgrade, 1989

World Development Indicators, The World Bank

"Prodaja po republikah in poraba reprodukcijskega materijala v republiki Sloveniji", Zavod Republike Slovenije za statistiko, Ljubljana, February 1991, p. 8 (Privredna komora Hrvatske: Analiza odnosa gospodarstva Hrvatske s drugim republikama u Jugoslaviji, Zagreb 1991.)

Republic of Croatia - Central Bureau of Statistics; elaborated by the Croatian Chamber of Commerce, Sector for International Relations.

Republic of Croatia - Central Bureau of Statistics; elaborated by the Croatian Chamber of Commerce.

Republic of Slovenia - Central Bureau of Statistics, October 2004.

Slovenia: economic transformation and EU accession. A World Bank country study, The World Bank, Washington, D. C., 1999 
Zoran Stiperski, Jelena Lončar - Changes in Levels of Economic Development among the States Formed in the Area of Former Yugoslavia

ZRSS, p. 8. (Privredna komora Hrvatske: Analiza odnosa gospodarstva Hrvatske s drugim republikama u Jugoslaviji, Zagreb 1991.)

ZRSS, p. 9. (Privredna komora Hrvatske: Analiza odnosa gospodarstva Hrvatske s drugim republikama u Jugoslaviji, Zagreb 1991.)

\title{
SAŽETAK
}

\section{Promjene u razinama ekonomske razvijenosti zemalja nastalih na području bivše Jugoslavije}

\author{
Zoran Stiperski, Jelena Lončar
}

Raspad Jugoslavije i ratovi na ovim područjima uzrok su djelomičnog raspada jugoslavenskog tržišta, raznih međunarodnih sankcija i prijetnji sankcijama, te uobičajenih opterećenja što dolaze s ratovima, dodatno je otežalo uspješan ulaz u dobro-funkcionirajuću tržišnu ekonomiju.

Najveću ekonomiju, od svih jugoslavenskih republika, (najviši ukupan društveni proizvod) od 1957. do 1988. g. imala je Srbija i Crna Gora. Srbija i Crna Gora sudjeluju s 39-40 \% u ukupnom tadašnjem društvenom proizvodu Jugoslavije. To se sudjelovanje ne mijenja kroz 30-tak godina. Naravno, većina tog sudjelovanja odnosi se na Srbiju, jer udjel Crne Gore u Jugoslaviji je malen - kreće se oko $2 \%$, dok udjel Srbije u Jugoslaviji je 37-38 \%. Hrvatska je imala drugu najveću ekonomiju u Jugoslaviji s udjelom od 25 do $28 \%$. Upravo je Hrvatska bilježila i najveća odstupanja od svih republike u doba Jugoslavije. Godine 1957. Hrvatska je sudjelovala u Jugoslaviji s gotovo $28 \%$ ukupnog društvenog proizvoda, da bi se do 1988. g. hrvatsko sudjelovanje smanjilo na $25 \%$. Treća najveća ekonomija bila je slovenska sa sudjelovanjem oko $17 \%$ u društvenom proizvodu. Bosna i Hercegovina sudjelovala je s blizu $13 \%$, a Makedonija s blizu $6 \%$ u društvenom proizvodu Jugoslavije. Podijelimo li bivšu Jugoslaviju na zapadni i istočni dio, tada zapadni dio - Slovenija, Hrvatska i Bosna i Hercegovina (SHBiH) - ostvaruje $55 \%$ društvenog proizvoda Jugoslavije, a istočni dio - Srbija, Crna Gora i Makedonija (SCGM) - 45 \%. Podjela brojnosti stanovništva na zapadni i istočni dio je gotovo 50:50 \%.

Tradicionalno najrazvijenija republika u bivšoj Jugoslaviji bila je Slovenija koja je imala od $74 \%$ do $100 \%$ viši društveni proizvod po stanovniku od jugoslavenskog prosjeka u razdoblju od 1957. do 1988. g. Hrvatska je bila druga najrazvijenija republika s $20 \%$ do $26 \%$ višim društvenim proizvodom po stanovniku od jugoslavenskog prosjeka.

Od republika, Srbija i Hrvatska, kao dvije najveće ekonomije, bile su i najveća tržišta (unutarjugoslavenska tržišta) za ostale republike 1987. g. Hrvatska je bila najveće tržište za Sloveniju i Srbiju, a Srbija za ostale republike.

Nakon raspada Jugoslavije i stvaranja pet novih država, rata te doba tranzicije dolazi do znatnog narušavanja postojećeg omjera razvijenosti.

Kao što se moglo očekivati, došlo je do velike razlike u razvijenosti među novonastalim državama na prostoru bivše Jugoslavije. Slovenija i Hrvatska postale su još razvijenije i udaljile se 
od prosjeka prostora bivše Jugoslavije, a Srbija i Crna Gora, Makedonija, te Bosna i Hercegovina udaljile se od prosjeka u suprotnom smjeru. Dakle, kompozicija vlaka značajno se razvukla.

No, posebno je zanimljiva promjena omjera triju najvećih ekonomija: Hrvatska, Slovenija te Srbija i Crna Gora. Došlo je do značajnoga ekonomskog rasta Slovenije i Hrvatske, te do velikog pada Srbije i Crne Gore poslije 1988. g.

Pitanja što će biti u budućnosti? To nitko ne zna. Za pretpostaviti je da će Srbija i Crna Gora nešto smanjiti omjer prema Hrvatskoj i Sloveniji, ali upitno je hoće li se približiti omjeru iz razdoblja postojanja Jugoslavije. To je za sada teško pretpostaviti, ali možemo pretpostaviti da će udaljenost u ekonomskoj razvijenosti između Slovenije i Hrvatske s jedne strane, te Srbije i Crne Gore, s druge strane, u bližoj budućnosti biti veća nego u doba bivše Jugoslavije.

Jači izvoz na području bivše Jugoslavije unutar bivših republika, a sada zasebnih država otežavaju izvjesne političke napetosti i sjećanja na nedavni rat. Vrlo je vjerojatno da je srpska agresija na Hrvatsku sada prilično otežavajući činitelj za srpski izvoz na hrvatsko tržište.

Kao zaključno možemo pretpostaviti da je noviji skok u robnoj razmjeni između država bivše Jugoslavije kratkoročni skok, posljedica dugotrajnog ometanja slobodnije međusobne trgovine. No, pretpostavka je da će uskoro doći do zasićenja, jer osnovna usmjerenost je susjedno regionalno tržište u Zapadnoj Europi i ostala svjetska tržišta.

Zoran Stiperski, PhD, associate professor Department of Geography, Faculty of Science Marulićev trg 19, Zagreb, Croatia e-mail: zstiper@geog.pmf.hr

Jelena Lončar, assistant

Department of Geography, Faculty of Science Marulićev trg 19, Zagreb, Croatia e-mail: jloncar@geog.pmf.hr 